\title{
Empirical Study of Re-Establishment of Municipal Utilities in Germany
}

\author{
Takuo Nakayama \\ Graduate School of Economics, Kyoto University, Kyoto, Japan
}

Email address:

nakayama@econ.kyoto-u.ac.jp

To cite this article:

Takuo Nakayama. Empirical Study of Re-Establishment of Municipal Utilities in Germany. International Journal of Business and Economics Research. Vol. 6, No. 5, 2017, pp. 124-133. doi: 10.11648/j.ijber.20170605.16

Received: September 25, 2017; Accepted: October 14, 2017; Published: November 16, 2017

\begin{abstract}
In recent years, a number of new municipal utilities (Stadtwerke) re-established in energy sector in Germany. From the end of 1980s through the 1990s, the privatization of utilities and outsourcing was a dominant trend; recently, a reverse paradigm can be seen, with local governments showing a remarkable tendency to establish new public energy companies. In this paper, focusing on trends in re-municipalization of energy business occurring in Germany, especially focusing on decentralized power systems by municipalities. On the other hand, this paper confirmed the concept of re-municipalization and clarified the goal that the local governments are aiming for. Through the activities, these municipalities are aiming to work at all stages of the value chain of new local economic value added creation. These activities cover many areas related to energy supply.
\end{abstract}

Keywords: Municipal Utility, Re-Municipalization, Local Value Added, Decentralized Energy System, Renewable Energy

\section{Introduction}

At the 2015 United Nations Climate Change Conference (COP 21), held in Paris, a framework was adopted to limit increases in the world's atmospheric temperature to no more than $1.5^{\circ} \mathrm{C}$ above pre-industrial levels. With two hundred countries and regions participating in the framework, which includes measures to prevent global warming on or after 2020 that are partially legally binding, the Paris Agreement is a historical international agreement that follows in the footsteps of the Kyoto Protocol.

A vast energy transformation is needed to reduce the $\mathrm{CO}_{2}$ emissions of both advanced and emerging nations, as well as to allow us to catch a glimpse of a society that is not dependent on nuclear energy. Put another way, there is a very real need to make energy utilization, including the introduction of renewable energy, heat utilization, and energy conservation, more efficient.

Having accepted this global arrangement, an important issue is how to go about making energy utilization more efficient. This must bring about sustainable development at the regional as well as the global level.

In Germany in recent years, the energy sector has seen a large number of new municipal utilities (Stadtwerke) re-established. This can be seen in large cities such as
Hamburg and Berlin as well as in agricultural communities. From the end of 1980 s through the 1990 s, the privatization of utilities and outsourcing was a dominant trend; recently, a reverse paradigm can be seen, with local governments showing a remarkable tendency to establish new public energy companies [1], [2].

In this way, trends in local government water service and energy fields have become exactly the opposite of their former neo-liberal forms [2]. Many local governments recognize these new trends as increasing public and private value. Furthermore, this "Energy Transition" (Energiewende) has produced a vast array of new opportunities for regions to implement energy supply [3], [4].

In essence, over the last 70 years Japan has also seen vertically integrated/regionally monopolized electricity power systems go through increasingly major transformations, beginning with the liberalization of the retail sector in April 2016. However, despite energetic arguments for unbundling the power generation and retail sectors from the power distribution sector, there was no such argument for unbundling the electricity supply and distribution sectors.

If the electricity supply and distribution sectors could be unbundled, with local authorities and public corporations participating in the distribution of electricity, one could envision a scenario involving a transition to energy dispersed 
from the regions. In this sense, the tendency of local governments in Germany to establish new municipal utilities (Stadtwerke), repurchase power grids, and implement energy projects has significant implications.

\section{Method}

In this paper, we consider what a newly organized municipal corporation in Germany is like and exactly what kind of goals are set for re-establishing public ownership, based on a scoping study conducted by the Wuppertal Institute for Climate, Environment and Energy [5].

By 2016, Germany had updated almost all of its existing power grid concessions. Taking advantage of this, two-thirds of German municipalities were reported to be considering buying back power-generation facilities and power grids [5]. Establishing its own public corporation is an important first step for a municipality pursuing a strategy of sufficiently utilizing the potential of the region's energy policies [6].

Local government taking possession of power grids has a host of merits in the present day. These are summarized in the following six points [7].

The first point is the supplying of energy on one's own, a core issue of public service. If distribution networks are in the hands of the municipality, these become the responsibility of the various regional players. "Players" here refers to local government policy makers and the local merchants and organizations that have been thrust into action as a result of these initiatives. The citizens and enterprises that serve as customers are recognized as the individuals in immediate charge of these public services. Because an adequate price is of utmost importance when it comes to the value of the energy provided, the profits gained from electricity distribution projects are of secondary importance.

Second, we can expect the creation of added value for the regional economy. Municipal infrastructure contributes directly to the creation of added economic value in the region. Profits gained from the management of power grids and business activities remain in the region. These do not flow to the headquarter offices of large companies, or their shareholders, outside the area. What's more, the management of power grids ensures continuous steady employment, with this know-how both created and utilized locally.

Third, because they are publicly held, municipal public corporations can obtain resources needed to maintain public welfare. While they engage in corporate activities, public corporations are able to offset divisions that produce profits, such as energy projects, with divisions that produce losses, such as local public transportation and swimming pool maintenance. Taxes that can be offset are advantageous for municipal utilities.

Fourth, there is an expectation for potential synergistic effects for the development of new businesses. In other words, with regards to distributed energy systems resulting from combined electricity supply, the introduction of hybrid systems $^{1)}$ will make it easy to optimize multiple energy systems concurrently. Above all, when it comes to distributed energy systems resulting from cogeneration, the introduction of a hybrid system simplifies the concurrent optimization of multiple energy systems. Thus, there are several techniques for manifesting the synergistic potential at the municipal level [8].

Fifth, there is the advantage that this is close to citizens. In accordance with the level of value chains for the added economic value of distributed energy, it becomes feasible to advance into different business sectors. An example of this can be seen with cogeneration supply systems and the like. Because municipal utilities are close to their customers, it is possible to develop an energy service that meets various demands and, sometimes, it is even possible to create a custom-made solution. The strength of the municipal corporation is that a feeling of solidarity can be created with the customer.

Sixth, there is the expectation of future marketability. Presently, there is a close relationship between smart grids, smart metering, and electric cars, and infrastructure components with these can be used for market development purposes. For example, the administration and optimization of local transport that makes use of electricity is a matter of important concern and interest for local government. These types of innovations are set to be important options for the near future.

Thus, the repurchase by municipal utilities of power grids that had previously been sold off, or the establishment of municipal utilities is thought to be a fundamental prerequisite for efficient energy utilization by means of rapid energy transition and smart grids, as well as constructing a meaningful supply structure overall [9].

The local governments of Germany are intensifying their energy transition efforts by means of various newly organized municipal utilities. This is because Article 28 of the German Constitution guarantees the independent design of energy-related works as a municipal right.

Many local governments have formulated climate change measures and integrated plans of action, with municipal utilities being responsible for the actual qualitative effects of these. There are overlapping-such as public safety authorities, planning authorities, and community architecture-between the municipal corporation and the local administration, making meaningful group projects possible.

Thus, when it comes to energy transitions, municipalities engaged in re-establishing public ownership play an especially important role. By maintaining municipal utilities unique to their municipality, they gain the opportunity to promote the reconstruction of a green energy supply that is ecologically beneficial [12], [16].

\footnotetext{
1) Here, "hybrid systems" indicates smart systems conceived of as an energy supply-and-demand method, because of the prospects for renewable energy in the future. Here electricity, gas, and thermal feed lines are to be linked and controlled. Moreover, depending on supply and demand, energy is supplied to transportation, electricity, and heating, while carrying out separate conversion, storage, and transportation.
} 


\section{The Reality of the Municipal Corporation in Germany}

In Germany, power grid concessions are normally renewed once every 20 years. This process involves an increase in newly established municipal utilities (Stadtwerke) and village utilities (Gemeindewerke). From 2005 to 2012, at least 72 municipal and village utilities were established $[5]^{2)}$.

In this section, the municipal and village utilities that are the subject of our analysis were engaged at a bare minimum in the electric power business. We only looked at newly established businesses. For example, municipal utilities that only involved a changeover to limited liability companies $(\mathrm{GmbH})$ from administrative corporations (Eigenbetrieb), and municipal utilities that deal only with construction work, were not addressed. Moreover, business areas that have expanded by means of repurchasing electrical distribution networks of existing municipal and village utilities that deal with gas and water supply were also not covered [5].

In Germany, it is compulsory to clearly separate power generation, electricity supply, and electricity retail sectors by unbundling regulations. Meanwhile, with municipal utilities in which municipalities provide majority investments, there are no companies that only operate power grids for general strategic and corporate management purposes. Serving as general corporations, almost all municipal utilities engage in corporate activities at the stage where they create multiples of added economic value.

Put another way, in thinking about the newly organized municipal utilities and power grids that have been re-established under public ownership, we can consider municipal utilities to be comprehensive companies engaged in relevant corporate activities [2].

\subsection{The Location and Clustering of Newly Established Municipal and Village Utilities}

Figure 1 shows the location of municipal and village utilities established on or after 2005. As this Figure indicates, newly established public corporations can be confirmed as forming regional clusters.

The Hamburg-Schleswig region makes up Cluster 1; the Hanover area makes up Cluster 2; the Wolfsburg region makes up Cluster 3; the eastern Westphalia-Munster region makes up Cluster 4; the Rhineland region makes up Cluster 5; the Stuttgart-Neckar region makes up Cluster 6; the Black Forest makes up Cluster 7; the Lake Constance region makes up Cluster 8; and the Munich region makes up Cluster 9.

Of these areas, public corporations have gained an especially strong foothold in Clusters 6, 7, and 8 of Baden-Württemberg state. After Baden-Württemberg, the next regions that have seen a proliferation in public corporations are Clusters 4, 5, and 6 in North

2) German Institute of Urban (Affairs (Difu: The Deutsches Institut fur Urbanistik) and The Association of Municiple Enterprise (VKU: Verband Kommunaler Unternehem) also carried out a rough assessment through market surveys, but data made up completely of this numerical scope does not thus far exist.
Rhine-Westphalia and Clusters 2 and 3 in Lower Saxony.

Moreover, newly established municipal and village utilities are unevenly distributed, with some $95 \%$ of these found in the former West Germany area. There is clearly a disparity between east and west when it comes to newly established public corporations. It is assumed that, with regards to clustering, neighboring municipalities have had positive experiences when it comes to newly establishing and re-establishing municipal utilities, and that there is increased momentum for activities in these sectors for one' $\mathrm{s}$ own local government. For example, the successful examples of Schönau Electricity Power Company (EWS) and Alp Electric Power Company Geislingen-Steigen in Baden-Württemberg are representative examples of a certain ripple effect being produced in the surrounding regions.

Schönau Electricity Power Company has created a partnership-like relationship with such municipal utilities as the Stuttgart Municipal Corporation and Titisee-Neustadt Municipal Corporation. When another municipality established a municipal utility, Schönau Electricity Power Company not only offered their own experience and administrative know-how; they also invested $50 \%$ of the capital provided to Titisee-Neustadt and $40 \%$ of the capital provided to Stuttgart's municipal corporation. Moreover, Schönau Electricity Power Company also provided 50\% of the capital for Schwäbisch Hall [10].

\subsection{The Population of Municipalities Served by Newly Established Municipal and Village Utilities}

So now to investigate the populations covered by these municipal and village utilities. Figure 2 shows the population represented by 72 public corporations ${ }^{3)}$. These population classifications conform to the scale of both power grid operations and the conferment of government ordinances.

As clearly shown by this Figure, municipalities with populations ranging from 10,001 to 25,000 persons or their affiliates have the largest number of municipal and village utilities. Moreover, in almost all cases, the population covered by a single public corporation ranges from 10,001 to 50,000 persons, with 61 of the 72 public corporations serving this population range. On the other hand, towns with a population of 10,000 persons or fewer had 16 public corporations, making up about $20 \%$ of the total. It is thus significant that municipal and village utilities are established in small municipalities, where they can supply energy.

That said, in municipalities with populations of between 10,001 to 25,000 persons, it is no easy task to establish and manage municipal and village utilities. This is due to a lack of qualified professionals and technical know-how and the fact that labor is just too costly, as well as other factors. Moreover, procedures related to transferring power grid concessions are quite complex, and present a high hurdle for the small municipality.

3) Because multiple municipalities formed alliances to establish municipal utilities, the number of public utilities and municipalities are not always the same. When multiple municipalities come together to establish public utilities, the total population of all municipalities is calculated. 
In these small municipalities, the public corporation alliances and joint conferences between municipalities

mentioned in (1) are meaningful. Put another way, "strategic partnerships" are becoming important.

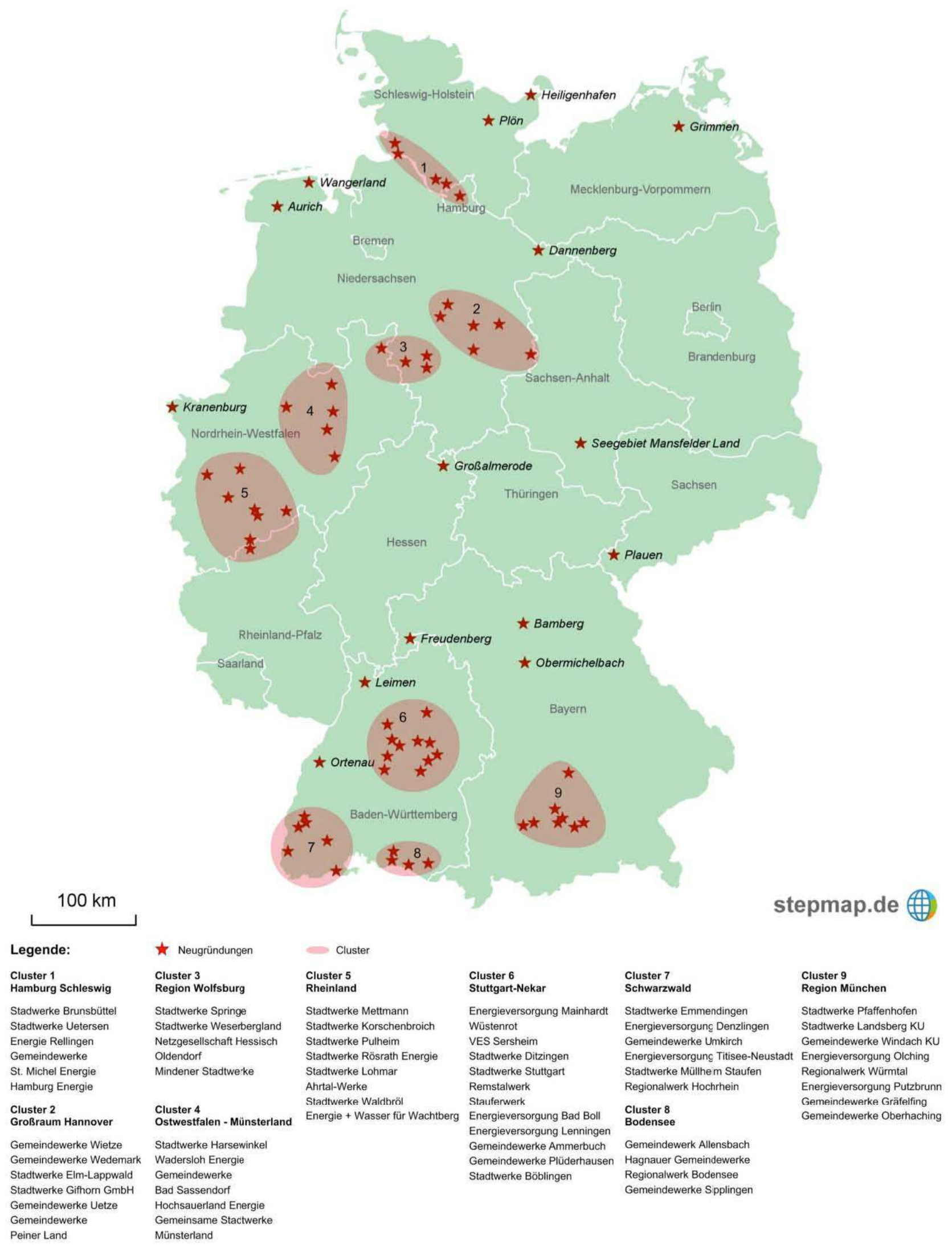

Source: [5]

Figure 1. Municipal and village utilities newly established on or after 2005. 


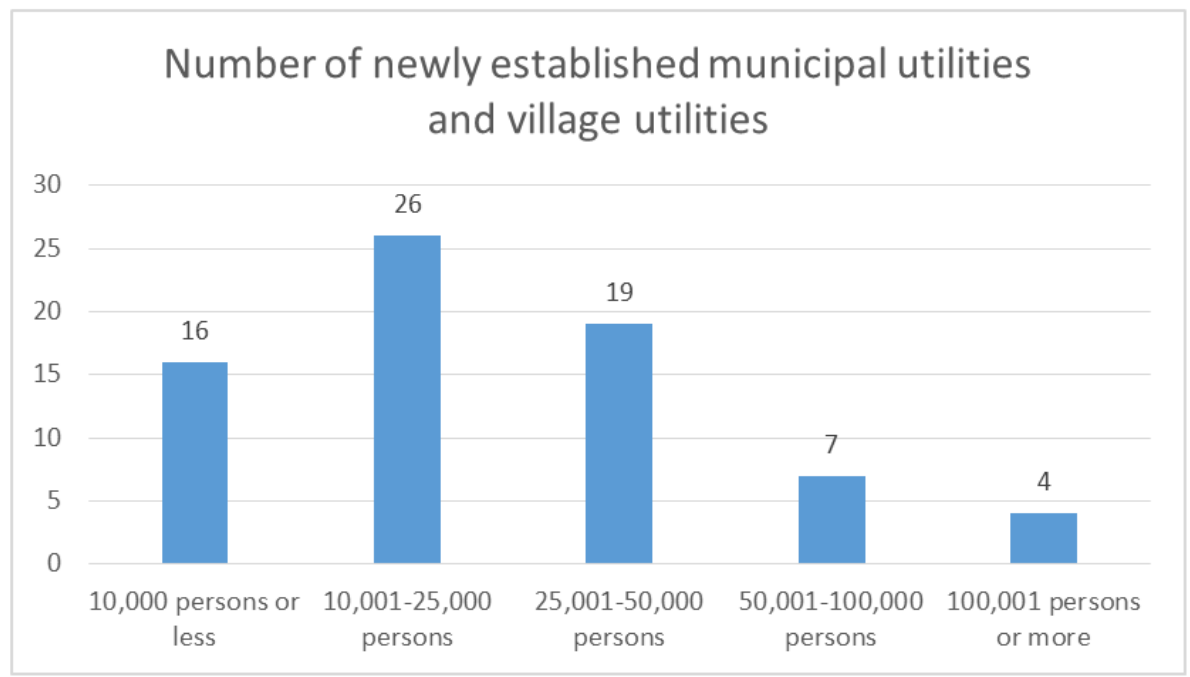

Source: Created from [5].

Figure 2. Numbers of newly established municipal utilities and village utilities by population.

[Figure: Number of newly established public corporations; 10,000 persons or less; $10,000-25,000$ persons; 25,00150,000 persons; $50,001-100,000$ persons; 100,001 persons or more; Population]

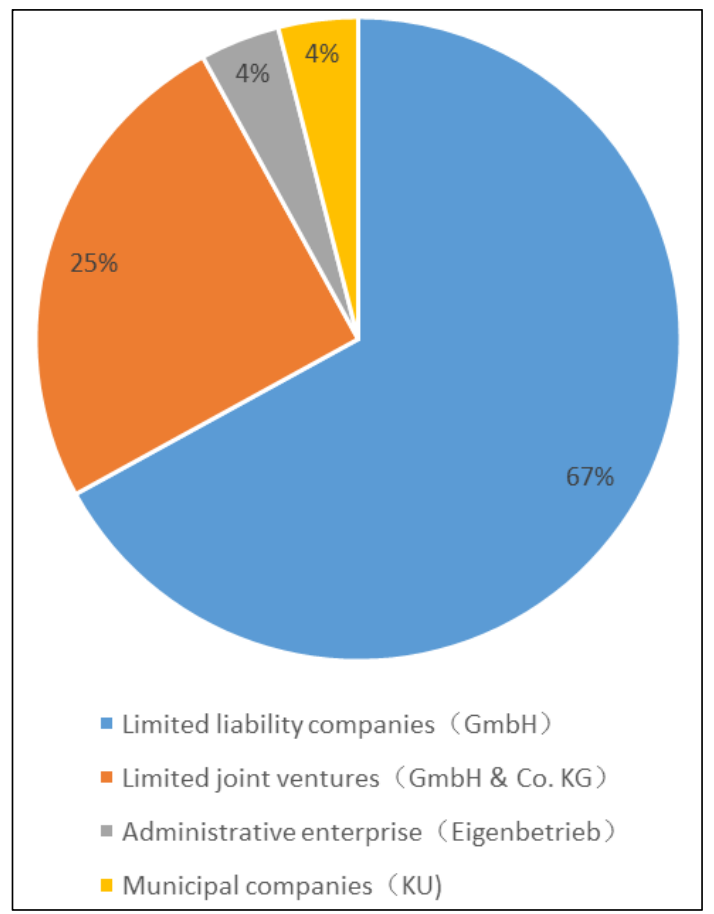

Source: Created from [5].

Figure 3. The Corporate Form of Newly Established Municipal and Village Utilities.

(Figure 3. Administrative enterprises (Eigenbetrieb); Municipal utilities (KU); Limited joint ventures ( $\mathrm{GmbH} \& \mathrm{Co}$. $\mathrm{KG})$; Limited liability companies $(\mathrm{GmbH})$ )

Now, as Figure 2 indicates, there are almost no municipalities with a population of 50,000 or more that have seen municipal utilities newly established. This is due to the fact that municipalities of this size already possess their own municipal utilities.

\subsection{The Corporate Form of Newly Established Municipal and Village Utilities}

Organizational form under private law plays an important role in the establishment of utilities in Germany. Regional organizations created by municipalities - including municipal and village utilities - may fundamentally take any corporate form under corporate law. However, the duty for municipalities to provide restitution under municipal law is capped at a certain amount, so they cannot select unlimited partnerships (OHG), limited partnerships (KG), limited share partnerships (KgaA), and non-registered NPO associations (nicht rechtfähige Verein). Common stock companies (AG) may be established in a straightforward fashion but these are geared toward large companies ${ }^{4}$.

Useful business forms for carrying out such economic activities include limited liability companies, limited joint ventures, registered cooperatives (eingetragene Genossenschaft), registered NPO associations (eingetragener Verein) and private foundations.

With corporate forms approved in an organizational format under private law, normally publicly held companies (AG) and limited liability companies $(\mathrm{GmbH})$ are subject to consideration. An organizational form under public law may also be selected. Most of these are administrative enterprises (Eigenbetrieb).

The 72 newly established municipal and village utilities were for the most part classified into four types. These were:

(a) Limited liability companies $(\mathrm{GmbH})$.

(b) Limited joint ventures $(\mathrm{GmbH} \& \mathrm{Co} . \mathrm{KG})$.

4) fes 2004: A Guide to Implementation Within Local Government; The Economic Enterprises of Local Governments (Loose-leaf collection) (Wegbeschreibung für die kommunale Praxis Die wirtschaftlichen Unternehmen der Gemeinde (Loseblattsammlung)) 
(c) Administrative enterprise (Eigenbetrieb).

(d) Municipal companies (KU).

(c) Administrative enterprise (Eigenbetrieb) here refers to independent administrative utilities. These are administrative enterprises that have been incorporated into non-corporate administrative organizations.

(d) Municipal companies (KU) are a special form seen only in the state of Bavaria and are based on a special provision of the state's municipal government law. Municipal companies (KU) have a corporate form whereby they are referred to as utilities under public law, and are regarded as independent companies (Bavaria State Municipal Law [BayGO] Article 89).

Figure 3 shows the ratios of the different corporate forms for municipal and village utilities. There are an overwhelmingly large number of (a) limited liability companies $(\mathrm{GmbH})$, making up some $67 \%$ of the total. This corporate form was selected because it is suitable to the realities of the distributed energy market. Limited liability companies allow for capital participation by third parties. These third parties that provide capital can become powerful strategic partners.

Limited liability companies that have been established based on private law differ from administrative enterprises, in that they are distinctive legal entities. In other words, they are not covered by administrative accounting and are separate from municipal administration in terms of assets. Accordingly, limited liability companies are only obligated to provide capital in the case of damages. In contrast, in the case of utilities established based on public laws (administrative entities/municipal utilities), municipalities must bear unrestricted responsibility for the debts of administrative enterprises. Should a municipality go bankrupt, in the end the state is responsible for its debt.

Specifically, there is much risk in efforts to buy back power grids and re-establish them as public entities. For example, it is very costly when a suitable purchase price cannot be agreed to with the existing owner of the grid's business rights, resulting in postponement of handing over the grid and a lengthy legal battle.

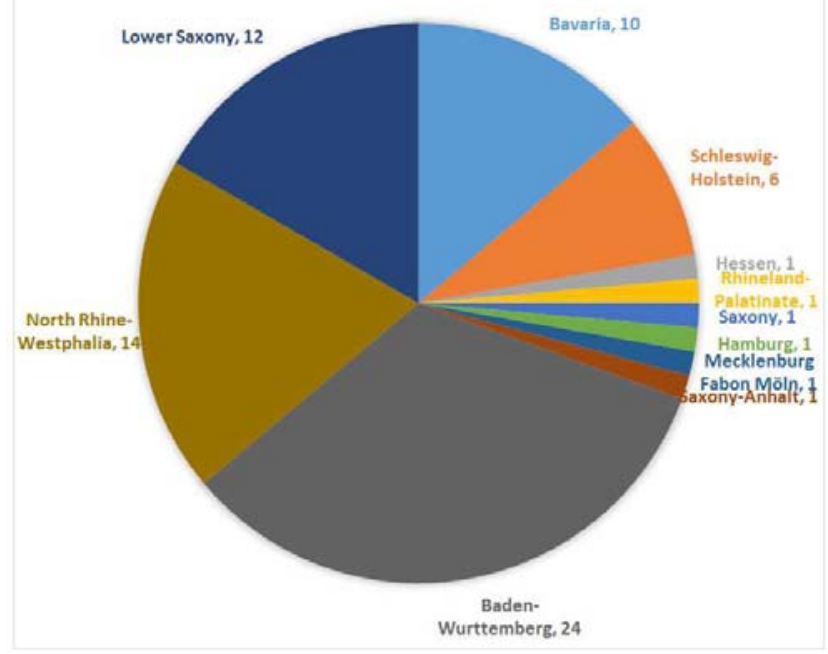

Source: Created from [5].

Figure 4. Numbers of municipal and village utilities established by state.
[Figure: Lower Saxony, 12; Bavaria, 10; North Rhine-Westphalia, 14; Baden-Wurttemberg, 24; Schleswig-Holstein, 6; Hessen, 1; Rhineland-Palatinate, 1; Saxony, 1; Hamburg, 1; Mecklenburg Fabon Möln, 1; Saxony-Anhalt, 1]

On this point, the limited liability company corporate form is a useful strategy for limiting the obligation for damages. Moreover, because local municipalities make up a majority of investors, another merit is that they are not only able to influence management; they can also be established relatively easily. This is why municipal and village utilities overwhelmingly take on the limited liability company corporate form.

\subsection{The Regional Ubiquity of Municipal and Village Utilities}

Public corporations are being newly established in 10 of the 16 German states. Figure 4 shows the number of municipal and village utilities newly established in the various states. Municipal and village utilities established between 2005 and 2012 in Berlin, Brandenburg, Bremen, Saran, and Thuringen states are not shown.

Of particular note is that in Baden-Wurtenberg (BW) alone there were 24 cases of municipal and village utilities being established; this made up $33.3 \%$ of the total. Next up is North Rhine-Westphalia with 14 new public corporations, making up $19.4 \%$ of the total, then Lower Saxony with 12, making up $16.7 \%$ of the total. These three states alone saw 50 municipal utilities newly established, making up about $70 \%$ of the total. These numbers beg the question: why is there such pronounced regional bias in the establishment of public corporations?

First, it is thought that this is related to the timeframe for renewal of concessions for the power grid. However, it is obvious by the fact that these three states alone represent $70 \%$ of all newly established municipal and village utilities that there is no relationship between the renewal period and the new establishment of public corporations.

Next, there is the political situation: the circumstances surrounding the political majority in the local legislative assembly and political decision makers are factors in opinions regarding the new establishment and re-establishment of municipal utilities.

The Social Democrats (SPD), Green Party (Bündnis 90/ Die Grünen) and The Left (Linke) are basically in agreement on the strategy of re-establishing municipal utilities. Conversely, the Free Democratic Party's (FDP) thinking on municipal utilities and the re-establishment of public ownership seems to range from vague skepticism to decisive opposition. The Christian Democratic Union (CDU) frequently collaborates with the FDP at the municipal level.

We can consider that it is fundamentally difficult to decide to re-establish a municipal corporation from these political partnerships at the municipal level. However, in municipalities where the CDU holds a clear majority, we can see strategies for the re-establishment of public ownership. Taken together, it is hard to say that a political majority in the 
municipal assemblies is a decisive reason for the uneven distribution of newly established municipal utilities regionally.

On the other hand, the quality of services provided by conventional power grid concessionaires is a key reason behind the establishment of municipal utilities. In other words, there was dissatisfaction with these concessionaires. In Baden-Wurtenberg State, almost all municipalities that established new public corporations saw the major power provider EnBW operate their grid at one time. In North Rhine-Westphalia, the major power provider RWE or its regional subsidiaries managed the power grid. In Lower Saxony, the major operator E.ON owned the concessions for the power grid and, in many cases, carried out operations. Large-scale centralized power generation of coal, brown coal, nuclear power, and the like were central to these major companies.

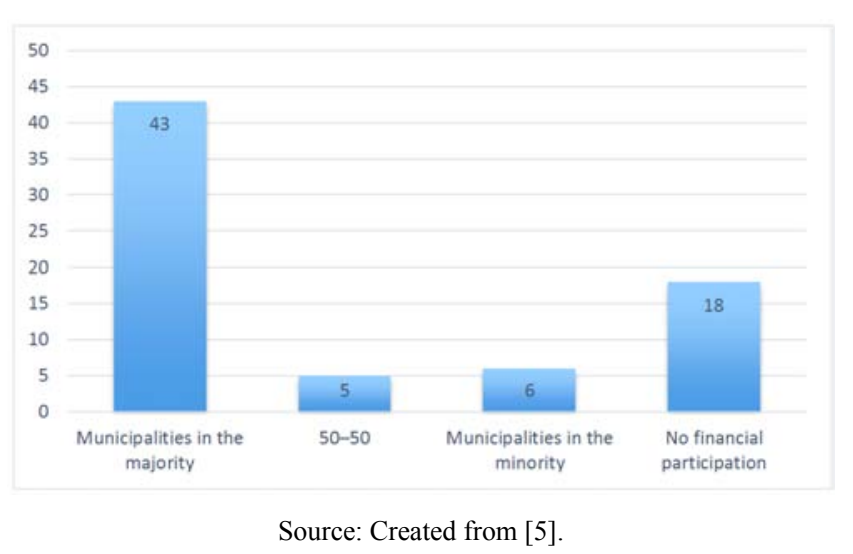

Figure 5. The Makeup of Partners for Municipal and Village Utilities.

[Figure: Municipalities in the majority; 50-50; Municipalities in the minority; No financial participation]

Moreover, another important reason for the uneven distribution of companies is the municipal law of the state. Autonomy laws stipulate the degree of economic activity permitted by local bodies of municipalities. As a part of this, the municipality has the right to establish companies (public corporations) as prescribed in the municipal law of each state.

Here, we take up the question of just what kind of tasks public corporations should pursue in harmony with the basic rules of a market economy. The interpretation varies, depending on the political party. As a result, the scope of tolerance of economic activities by municipalities established by the autonomic law of the state varies depending on the state. This scope of tolerance ranges from narrow to broad interpretations, based on the principle of complementation.

Last, models produced by the pioneer municipality are extremely decisive in the establishment of new public corporations. In Baden-Wurtenberg, municipalities such as Schönau and Schwäbisch-Hull can be thought of as pioneering municipalities that become driving forces in the establishment of municipal and village utilities and the re-establishment of public ownership of power grids. The establishment of public corporations is concentrated in the Black Forest region and the outskirts of Stuttgart, explaining the formation of clusters.

The reason that few municipal and village utilities have been newly established in the five former East German states fundamentally involves provisions settled after the reunification of East and West Germany. The "Reconciliation of Power" of 1992 gave the municipalities of the former East Germany the right to demand the return of state-owned municipal utilities. As a result, more than 140 municipal utilities that supply electricity, gas, and district heating were born [11]. In other words, in the former East German region, the establishment of urban public corporations and the re-establishment of public ownership had already been strongly promoted about 20 years ago.

\subsection{The Owners of Newly Established Municipal and Village Utilities}

So who owns these newly established municipal and village utilities? The focus here - the issue at hand-is whether the municipality has drawn partners and, if so, what percentage of these partners participate in financing. When analyzing the ownership structure of new municipal and village utilities for whether partnerships are involved, we consider if these partnerships are between local governments or cooperation between local governments and the private sector. These types of partnerships are mainly used to reduce the financing of new companies (public corporations) or else to incorporate additional know-how into new companies.

Figure 5 shows the ownership structure of new municipal and village corporations. The 18 new public corporations with no financial participation do not accept the financial participation of partners. Examples include Hamburg Energy and the Stuttgart Municipal Authority. These public corporations possess large-scale energy supply areas. Moreover, prior to privatization as a result of electricity power liberalization, these corporations had experience managing their own municipal utilities.

These two re-established municipal utilities entered the retail sector, where they are now active. Because the existing power grid concession had not yet expired, neither power grid is being managed. However, ever since the contract period with the existing concession owner ended, there has been a tendency for municipal utilities to take over the operations of power grids. For these reasons, the establishment of the public corporation can be regarded as an important step in preparing for repurchase of a power grid.

Meanwhile, with "majority municipalities" accounting for 43 cases, most new public corporations are shown to be totally, or else mostly, under the ownership of municipalities. In the case of schemes for social participation, municipal and village utilities of neighboring municipalities are created directly. Looked at as a whole, we can see that the trend is for municipalities to prioritize partnerships with other municipalities in establishing public corporations. 


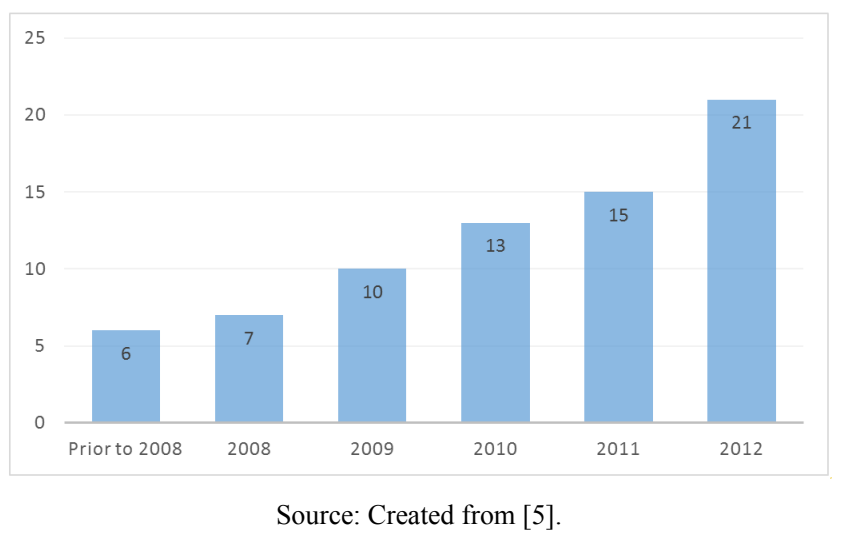

Figure 6. Year of establishment of municipal and village utilities.

[Figure: Prior to 2008; 2008; 2009; 2010; 2011; 2012].

The motivation here is to absorb know-how, communicate dissatisfaction to the former management company of the power grid, strengthen cooperative relations between regional and local government and create partnerships based on "shared viewpoints." Furthermore, municipal partners expect less in the way of dividend payments than private partners and there is also the expectation that there will be the potential for various synergistic effects as a result of mutual cooperation with neighboring municipalities.

Although we can often see cooperation with partners, there are many cases where local municipalities intend to supply their own energy. In almost all cases, we found that representatives of local government decided to attract experienced municipal utilities.

In many cases, former power grid management companies have applied to be the strategic partners of municipalities. However, of the 72 newly established public corporations covered in this section, 26 were accepting the financial participation of private strategic partners, not municipalities [5].

\subsection{Year of Establishment of Municipal and Village Utilities}

Figure 6 shows the number of municipal and village utilities established each year. There has been a trend toward ongoing increases since 2008. This reflects the spread of municipalities' efforts to enhance the regional design of the energy economy and their desire to improve the value-added creation process. Along with the maturation of technological and economic conditions, involving the utilization of diversified renewable energy and cogeneration facilities for local power generation, there is an increase in the desire to utilize this potential under the companies' own economic responsibilities.

In 2011, the Fukushima Daiichi Nuclear Power Station incident occurred, with the German Federal Government decision to pursue major changes in energy further strengthening this trend. Another reason is that many power grid concession contracts had expired. In many cases, repurchases of power grids occur after municipal and village utilities are established. Furthermore, in North Rhine-Westphalia, revisions to local law that are advantageous to local government have been effective since 2010 .

\section{Discussion}

Not all players in Germany welcome the re-establishment of public ownership. For example, the major power company RWE, the Federal Cartel Office, and the Federation of New Entrants to the Energy Market (BNE) were all critical, saying that "although major changes are needed when it comes to energy, re-establishing public ownership is not the correct strategy for implementation and that local government goals are unattainable."

The Cartel Office feels that the increase in power generation capacity by municipalities and municipal utilities is beneficial. This is due to the fact that it weakens the position of major power providers, improving market structure and energizing competition. On the other hand, it is critical of the trend of re-establishing the public ownership of power grids.

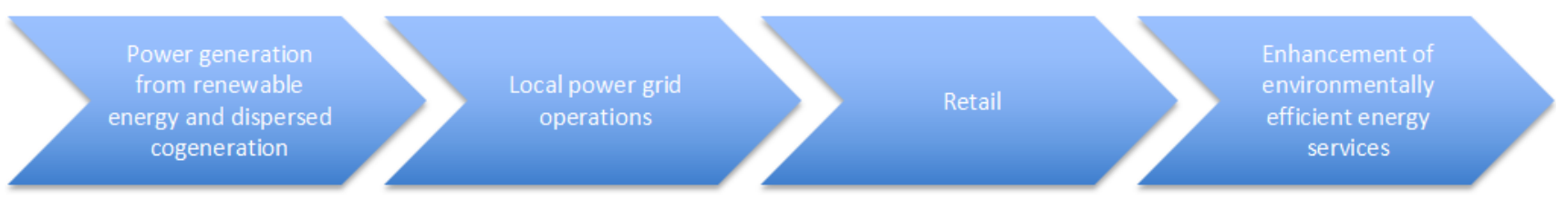

Source: Created based on [5].

Figure 7. Value chain showing creation of added value for the regional economy through re-establishment of public ownership.

[Figure: Power generation from renewable energy and dispersed cogeneration $\rightarrow$ Local power grid operations $\rightarrow$ Retail $\rightarrow$ Enhancement of environmentally efficient energy services]

This is because not only do such efforts serve to break down or otherwise scrap the entire power grid, increase grid usage fees, and facilitate increases in control operations, they also result in no realization of efficiencies borne out of coupled lines [12].

However, according to the North Rhine-Westphalia
Municipality Association Report and an assessment by the Federal Network Agency, there is no basis for the claim that small electric grid operators in the area are less efficient than large-scale ones. In addition, it has been found that, when a power grid is transferred from a major power grid management company, after the power grid has been assigned it is not uncommon to find signs of sloppy maintenance and operations by the former operator [6], [13].

Here I would like to redefine the concept of re-establishing public ownership that is actively taking place in Germany. For 
the newly established municipal corporation and public corporation, the re-establishment of public ownership is about more than just buying back and operating power grids and gas conduit networks; many of these public corporations aim to be active at all stages of the value chain for economic value-added creation [14], [15], [16].

In other words, of re-establishment of public ownership activities encompass many fields related to energy supply. These range from electricity, heat and gas production, trade, and power grid management to retail and customer service (Figure 7). By extending this value chain, public corporations can improve and stabilize their management foundations.

Another issue concerning of re-establishment of public ownership of regional energy supplies, which has become apparent in recent years, is the increase in demand for energy-saving services tailored to customers and industry. The importance of these services is increasing and is a business field that will bring significant benefits in the future. Municipal and village utilities, which are community-based companies, are particularly competitive in this area. Furthermore, highly developed information technology and the interactive control and coordination of power generation, distribution, and consumption that this also fosters the trend toward re-establishment of public ownership in Germany.

The establishment of more than 70 municipal and village utilities, and the buyback of more than 190 power grids, is proof that the trend of re-establishing public ownership of energy supply has become a major driver.

Furthermore, especially in rural areas, a rapid increase in " $100 \%$ Renewable Energy Areas"-where there is a movement to convert local energy supplies to renewable energy as soon as possible - as well as the establishment of more than 600 energy cooperatives, has led to more citizens wanting to participate in designing local energy supply.

In the future, it is anticipated that today's energy consumers will become producers of their own energy, designing their energy supply by proactively collaborating on regional energy transformation as "prosumers." In this respect, municipal and village utilities are close to citizens, familiar with local circumstances and have the ability to solve problems particular to the area.

In a major shift of federal-level policy, Germany is calling for companies involved in power generation, trade, transmission, distribution, and retail to comply with the fundamental restructuring process. As mentioned in the Preface, municipal and village utilities play a significant role in this conversion process.

The re-establishment of public ownership suggested in this section is set as a clear goal by municipalities. Unless, however, it is published as an official document such as a "Mission statement" or "Declaration of vision," it will remain unattainable. With new municipal and village utilities, it is effective to decide intermediate targets in which countermeasure packages and temporal/content viewpoints are defined [17].

\section{Conclusion}

In this paper, we have focused on trends in re-establishing public ownership of the energy business in Germany, with a special emphasis placed on the diversified power systems of municipalities. We began by consolidating the reasons why German municipalities want to re-establish public ownership of energy, including the concessions of power grids, into six components. We furthermore considered the actual situation surrounding newly established municipal utilities, by looking at the locations and clustering of municipal and village utilities, the population size of the municipality, its corporate form, regional ubiquity, owner, and year of establishment.

At the same time, we confirmed the concept of re-establishing public ownership, clarifying the goals that local governments aim for. Through the re-establishment of public ownership, these municipalities aim to be active at all stages of the value chain for the creation of new regional added value. The re-establishment of public ownership activities covers many areas related to energy supply, ranging from the production, trading, and grid management of electricity and gas to retail and customer service. What's more, including energy services-which are forecast to grow considerably moving forward-municipal and village utilities have a dominant presence.

It is impossible to apply the trend in Germany of dealing with energy - by newly establishing municipal and village utilities and re-establishing public ownership of power grids - directly to Japan. In Japan, there are cases of development projects running counter to the public interest, falling into debt after the collapse of the bubble economy, and losing the credibility of its citizens. Even if there were an attempt to make the power grid public, in Japan, there is no legal system to make this possible [18].

On the other hand, the necessity of integrally operating electricity, gas, heat, water supply, sewerage, transportation, and the like in the region is expected to increase. The main point to keep in mind here is that it should be important to involve municipalities subjectively neutral to every stakeholder. With the trend of re-establishing new public corporations and village utilities, taken up in this paper, we can see many strategic partnerships between municipal and village utilities but, in the author's opinion, strategic partnerships with private businesses are not necessarily to be repudiated in Japan.

The reason for this is that, traditionally in Japan, peripheral power business, including power grids, involve a system of regional monopolies of major power companies that have been ongoing for more than 70 years-ever since the "Distribution Control Order" that dates back to before the Pacific War-with managerial and technical know-how accumulated by major private companies and their affiliates. It is important to learn about the history of Japanese municipalities that managed energy as a business before World War II, and design a diversified energy system in the new area of the renewable energy mass introduction era. 


\section{References}

[1] Busshardt, B. (2014). Analysing the Remunicipalisation of Public Services in OECD Countries. Münchener Beiträge zur Politikwissenschaft, Geschwister-Scholl-Institut für Politikwissenschaft: München. (in German).

[2] Hall D. (2012). "Re-Municipalising Municipal Services in Europe." A report commissioned by EPSU to Public Services International Research Unit (PSIRU), Public Service International Research Unit, University of Greenwich. (in English).

[3] Wagner, O., Berlo, K., (2017) "Remunicipalisation and Foundation of Municipal Utilities in the German Energy Sector: Details about Newly Established Enterprises" Journal of Sustainable Development of Energy, Water and Environmental System, Volume 5, Issue 3, 396-407. (in English).

[4] Berlo, K., Wagner, O., Heenen, M., (2017) “The incumbents' conservation strategies in German energy regime as an Impediment to re municipalization: an analysis guided by the multi-revel perspective" Sustainability 9(1), 53. (in English).

[5] Berlo K., Wagner O. (2013). "Stadtwerke-Neugründungen und Rekommunalisierungen Energieversorgung in kommunaler Verantwortung Bewertung der 10 wichtigsten Ziele und deren Erreichbarkeit", SondierungsStudie, Wuppertal Institut für Klima, Umwelt, Energie $\mathrm{GmbH}$. (in German), translated by Takigawa K., Ikeda, N., Murakami, A., Nishimura, K (2015) "New Establishment and Re-Establishment of Public Ownership of Municipal Energy Utilities," The Wuppertal Climate, Environment and Energy Institute. (in Japanese).

[6] Berlo, K., Templin, W., Wagner, O., (2016) "Remunicipalisation as an Instrument for Local Climate Strategies in Germany: The Conditions of the Legal Energy Framework as an Obstacle for the Energy Transition" Renewable Energy Law and Policy Review, Volumel 7, Issue 2, 113-121. (in English).

[7] Müller-Kirchenbauer, J., Leprich, U. (2013). "Anforderungen an leistungsfähige Verteilnetze im Rahmen der Energiewende," EnWZ - Zeitschrift für das gesamte Recht der Energiewirtschaft, 2. Jg., Heft 3. (in German).

[8] Richter N., Thomas S. (2008). "Perspektiven dezentraler Infrastrukturen im Spannungsfeld von Wettbewerb, Klimaschutz und Qualität," Ansatz und Ergebnisse der
Forschungspartnerschaft INFRAFUTUR, Wuppertal Institut für Klima, Umwelt, Energie GmbH, (in German).

[9] Scheer, H. (2010). Der energethische Imperativ, Kunstmann München. (in German).

[10] Murakami, A. (2014). "Schönau Electric Power Company-A Pioneering Public Energy Company." Quoted in Murakami, A. /Ikeda, N. /Takigawa, K., "Aiming for 100\% Renewable Energy! Germany's Public Energy Utilities," Gakugei Shupansha, 106-110. (in Japanese).

[11] Becker, P. (2011). Aufstieg und Krise der deutschen Stromkonzerne-Zugleich ein Beitrag zur Entwicklung des Energierechts. Ponte Press. (in German).

[12] Bundeskartellamt (BKartA) "Stellungnahme des Bundeskartellamtes zur öffentlichen Anhörung des Wirtschaftsausschusses des Deutschen Bundestages zur Rekommunalisierung der Energieversorgung" BT-Drucksachen 17/3649, 17/3671, 17/3182 - am 24. January 2011. (in German).

[13] Ikeda, N. (2014). "Municipal Energy Utilities." Quoted in Murakami, A. /Ikeda, N. /Takigawa, K., Aiming for 100\% Renewable Energy! Germany's Public Energy Utilities, Gakugei Shupansha, Kyoto, 131-154). (in Japanese).

[14] Nakayama, T. (2015). "The Role of Municipalities in Promoting Regionally Dispersed Renewable Energy_Looking at the Re-Establishment of Public Ownership of Power Grids by Municipal Utilities in Germany," (Compilation by Morotomi, T., Renewable Energy and Regional Restoration) Nippon Hyoronsha, 171-188). (in Japanese).

[15] Deutsches Institut für Urbanistik (Difu) Difu-Berichte 3/2011. (in German).

[16] Universität Leipzig (2011). "Renaissance der Kommunalwirtschaft - Rekommunalisierung öffentlicher Dienstleistungen." Institut für Öffentliche Finanzen und Public Management, HypoVereinsbank Leipzig/München. (in German).

[17] Nakayama, T., Sando, A., Inoue H. (2014) “A German Survey Report on Power Liberalization, Renewable Energy, and the Re-Establishment of Public Ownership of Power Grids." Kyoto University iDER project Research Report Series No. 14-B-1. (in Japanese).

[18] Morotomi, T. (2015), Renewable Energy and Regional Restoration. Nihon Hyoronsha, 1-22, Tokyo. (in Japanese). 